\title{
Business Environments versus Corporate Survival in Estonia and Poland in 2001-2009
}

Submitted: February $1^{\text {st }}, 2010$

Accepted: March 11 th 2010

\section{Summary}

Corporate longevity is - in essence - determined by a company's intrinsic competitive advantage (sometimes dubbed a "moat") as well as exogenous factors: from business doing ease - to broader, macroeconomic and strategic factors.

In this study, we have endeavoured to compare the business environments and corporate sectors of two recent entrants into the European Union: Estonia and Poland. Overall, Estonia, thanks to greater resolve in post-communist liberal transition, has consistently ensured a superior corporate governance framework. Surprisingly, it is the macroeconomic and strategic steadiness that led to higher corporate survival in Poland. The global economic crisis of 2007-2009 is expected to further back this claim, as the patterns of macroeconomic growth for both countries are set to widen.

\section{Introduction}

"Corporate survival" and its wide-ranging ramifications for economic activity have been the leitmotiv of numerous scientific pursuits. The phenomena have thus far been examined in three major veins:

1. According to the first paradigm, or the so-called "ecological model", it is postulated that companies' shifts amongst economic sectors tend to mimic organic migrations amongst habitats. A distinctive feature of this approach is attempting to track corporate changes across three major strata (akin to "habitats"), i.e. start-up, fast-growth and declining enterprises, as per Poznańska (2008).

* Dr, adiunkt, Szkoła Główna Handlowa w Warszawie.

** Dr, adiunkt, Szkoła Główna Handlowa w Warszawie. 
2. The second perspective of corporate survival assumes that the market entry act is a make-or-break event in the life of an enterprise: only at that point is the entity able to prove its mettle (it either weathers this critical stage or continues to prosper, or goes out of business). Thus, the key drivers of this "survival of the fittest" are examined at market level (i.e. beyond the enterprise). It thereby assumed that structural characteristics, such as barriers to entry or exit, diffusion of high technologies substantially affect the longevity and growth patterns of start-ups.

3. The third train of thought focuses on the human capital/entrepreneurial aspect. Under this model, a great deal of significance is attached to the entrepreneur and his/her personal traits, such as expertise, education, appetite for risk. For example, Preisendorfer and Voss (1990) argue that the chances of corporate survival are directly correlated with the entrepreneur's personality.

Notwithstanding the aforementioned approaches, Poznańska (2008) and other scholars consistently stress the role played by institutional infrastructure in the direction and shape of corporate life cycles.

The following study examines the corporate survival concept in two European economies which joined the European Union in the past decade - Estonia and Poland.

\section{Ease of doing business - World Bank Group rankings}

The "Doing Business" database marketed in the media under the aggregate emblem of "Ease of Doing Business" and published annually by the World Bank Group represents the most cogent and comprehensive approach to measuring "business friendliness" in worldwide economies. The index (Doing Business, 2009) ranks economies from 1 (best) to 181 (worst) and is calculated as a simple average of percentile rankings across its 10 components - more methodology details are available from the relevant web site: Doing Business Ranking Methodology (2009):

The usefulness of the "Doing Business" index in predicting corporate longevity seems fairly instinctive: business survival ought to be a function of economic circumstances in which enterprises operate.

In the most recent index edition, Doing Business (2009), Estonia and Poland have displayed contrasting degrees of comfort in undertaking and maintaining business activity. Overall, Estonia (22) - in a peer group with Switzerland and Korea - markedly outran Poland (76): flanked by the Czech Republic and Pakistan.

Besides the overall distance between both economies in the ranking, it is its makeup that betrays veritable differences in the functionality of both economic systems. The general findings can be encapsulated in the following ways:

- Estonia - compared with Poland - clearly offers a more developed business culture on the vast majority of counts; the single discernible constraint relates to hiring workers (a legacy of Estonia's tight regulations protecting the domestic labour market from immigration, including lasting problems with the ethnic Russian minority); 
- Poland's score is ponderously hauled down by a chronically inefficient bureaucracy: any activity involving administrative assent or inference (be it business starts or closes, construction permits, property registrations or tax return filings) results in vexatious delays;

- Estonia is continuing to benefit from a sustained record of liberal transition: including a fiscal revolution (a flat tax introduced back in 1994), widespread access to the Internet (enshrined under several laws, which facilitates access to government agencies and minimises relevant red tape). Contrarily, Poland despite a gallant leap towards laisser-faire capitalism in the early 1990s, has regressed to economic over-protectionism as the new millennium drew near.

The "Ease of Doing Business" sub-rankings have been examined in greater detail in the following paragraphs of this paper.

\subsection{Starting a business (formalities, time, cost and capital needed) in Estonia and Poland in 2005-2009}

Unsurprisingly, the very idea of business survival hinges on incorporation (otherwise referred to as corporate association). Ultimately, to be able to measure the longevity of a body corporate, one has to extrapolate from the very premise of its prior establishment.

Founding a new business, Djankov et al. (2002), has required by far more effort in Poland than in Estonia in the period for which statistics are available. Suffice it to say that over the past five years no headway has been made in Poland in the number of formalities necessary to set up a business, and they are twice more numerous than those in Estonia as at 2009.

On average, it has taken a flat month to incorporate a business concept in Poland throughout 2005-2009 (no palpable reform in this category during this period). In discernible contrast, during the past half-decade, Estonia has curtailed the time lag between the conceptual and operational phases from some 72 days down to a mere week. This has mirrored a mental about-turn amongst local bureaucracy as well as sustained progress in technical sophistication (increasing reliance on Internet connectivity in business start-up proceedings).

Another critical factor relating to business inception is the cost side. The (Doing Business 2009) index measuring the cost of starting up a business (as a percentage of the country's per-capita income) has favoured Estonia over Poland. Evidently, an entrepreneur need think twice before embracing a business concept in Poland, as about one-fifth of the expected proceeds are likely to wind up covering incorporation fees. This represents a significant drag on entrepreneurship, which - by definition - implicates significant risk exposure. Estonia, contrariwise, has managed to cut this (risk related) factor to a diminutive 1.7.

An additional barrier to business growth is represented by minimal capital mandated by regulators in a given jurisdiction. Theoretically, shareholders' funds afford a measure of security to anyone willing to contract with a business entity (albeit in an era of global capital flows and creative accounting, practical reliability of this safeguard can 
often be elusive). From an entirely different perspective, a minimum capital threshold ties up seed/start-up capital, which (usually) comes at a high opportunity cost and might (otherwise) be allocated in a smoother and more economically attuned fashion.

The Polish jurisprudence has made considerable strides to lighten the burden of business incorporation; however, it still remains exorbitant by Estonian standards. In Estonia (as at 2009), the capital requirement tends to consume a little under a fifth of a citizen's income. In present-day Poland, it devours almost 170\% of personal earnings. As aforementioned, additional comfort derived by a company's stakeholders (from the thus enhanced capital régime) cannot be taken for granted in the practical circumstances of business liquidation, an issue examined later on in this paper.

\subsection{Dealing with construction permits (formalities, time and cost) in Estonia and Poland in 2006-2009}

Property development is essential for companies whose facilities rely, at least somewhat, on traditional infrastructure (i.e. the vast majority of enterprises in emerging economies). The number of formalities needed to obtain a construction permit serves as the inverse of flexibility with which enterprises are allowed to expand via recourse to traditional (physical) assets. Formal impediments to such expansion exist in both economies, yet Poland appears to be by far more bureaucratic in this respect (twice the number of procedures needed). Neither country has succeeded in deregulating the construction sector during the period covered by Doing Business reports (2006-2009).

The waiting period needed to initiate construction of a property hinders business growth for self-evident reasons: business concepts, inevitably, slip into (near) hibernation while permission is being eagerly awaited. Considerable stamina and patience are de rigueur for an applicant awaiting a construction permit in Estonia or Poland. Endurance is measured in months (over three in Estonia) and close to a calendar year (in Poland). Needless to observe, volatile economic circumstances can render a business endeavour completely futile in such a time span (a hazard absorbed by the entrepreneur and, obviously, scantly recognised by either officialdoms). No progress in this scope has been noted in the past four years in Estonia or Poland.

The cost of securing a construction permit adds to an already lengthy catalogue of economic constraints to business expansion. In line with the aforementioned yardsticks of formalism, Estonia has remarkably undercut Poland in terms of permit costs as a percentage of per-capita income in 2006-2009. Poland has noted discernible progress during the surveyed period; nevertheless, construction permit expenses have tended to outweigh per-capita incomes.

\subsection{Employing workers in Estonia and Poland (hiring difficulty, work schedule flexibility and firing difficulty) in 2004-2009}

Employment conditions are regarded as a preeminent consideration in undertaking and maintaining business activity. Entrepreneurs tend to favour circumstances enabling hassle-free adjustment to macroeconomic/industrial demand/supply cyclicality; rigorous 
employment laws hinder such adaptability. The composite "rigidity of employment" index is, pursuant to the relevant methodology - Botero et al. (2004) - composed of three subcategories, which have been examined hereunder.

The difficulty of hiring index (taking into account availability and duration of fixedterm contractual agreements as well as ratios of minimum to average wages) offers a proxy for the flexibility of a given labour market. Interestingly, Estonia - despite certain progress - has clearly lagged Poland in this category. This attests to the relative rigidity of the Estonian job market (with more flexible terms being available to employers in Poland: including, but not limited to, renewable short-term contracts).

The rigidity of hours index (availability of night shifts, workweek length, overtime extensions, shortness of paid annual vacation) demonstrates to what extent employers can fall back on the existing workforce to enhance short-term productivity, while keeping costs in check (e.g. in response to international or cyclical factors). There has been no change to working schedule arrangements in either country during the past five years. Furthermore, working habits in Estonia (index value: 80 ) tend to be more formalised than those in Poland (index value: 60), which confirms notions perceptible in the aforesaid hiring trends.

When the business climate sours, entrepreneurs may wish to downsize operations to retain financial liquidity. The difficulty of firing index (Doing Business, 2009) aims to gauge redundancy ease (its legality, contractual aspects, mass layoff protections as well as worker re-assignment/re-training constraints). By this standard, Estonian employers are confronted with higher barriers to headcount optimisation (index value at 60) than those faced by their Polish counterparts (index value at 40). Similarly to other employment related indices, neither country has managed to improve competitiveness in this critical area during the analysed period (2004-2009).

The firing costs indicator (Doing Business, 2009) demonstrates how laws relating to advance termination notice and severance pay/termination boost costs of regular salaries (measurable in weeks). The picture painted by firing dues in both countries for 2004-2009 corroborates the perception that Poland (40 weeks) has developed a more flexible employment market than Estonia (60 weeks). No betterment has taken place in either economy over the past half-decade.

\subsection{Registering property in Estonia and Poland (number of procedures, time and cost) in 2004-2009}

Registering property matters to entrepreneurs who, for a variety of reasons, need secure legal title to land and fixtures built upon it (a usual occurrence for businesses active in traditional industries). There has been no deregulation to property registration formalities in Estonia or Poland in 2005-2009, according to Doing Business (2009). Interaction with local bureaucracy has, statistically, been twice as arduous in Poland (6 encounters needed) as it is in Estonia (3 contacts necessary).

The time required to affect a formal transfer of legal title to a piece of property has been estimated at 51 days in Estonia and at a staggering 197 days in Poland throughout 
2005-2009. Sadly, in the course of the past five years, no progress has been noted in either economy in this regard.

Costs attributable to property registration play a major role in overall business models. Fortunately, their scale in Estonia and Poland is miniscule, what is more dramatic improvement took place in both countries over the past three years (2007-2009). This idyllic perspective is somewhat marred by more practical references (the continued bull market for property in the new European Union countries per se slashed the proportion of registration fees in soaring property valuations).

\subsection{Getting credit (strength of legal rights, credit information depth and credit bureau coverage)}

The database (Doing Business, 2009) contains rankings of credit environments existing in individual economies under survey. Effective access to debt financing represents a fundamental characteristic of an economic system and considerable leverage for corporate growth, especially in emerging countries, where the financing gap is especially hard to bridge. Recent empirical findings relating to challenges arising from the funding of young companies in the circumstances of an emerging economy (viewed from the perspective of a Latin American fund), can be perused in de Angulo and Lopez (2005).

The strength of legal rights index: Doing Business (2009), a subdivision of the "getting credit" category, Djankov et al. (2007) helps to pass judgment on the availability of legal recourse in collateral and bankruptcy proceedings. Accordingly, its objective is to assess the extent of coverage and flexibility with regard to various asset classes (including working capital) being put up for collateral; collateral registry practices and well as the "pecking order" or creditors (who are usually prioritised in the event a bankruptcy); a general reflection on the tempo of bankruptcy proceedings and availability of out-of-court settlement mechanisms.

Basing on the (Doing Business, 2009) "legal rights index", Poland (rated 8) has ensured a more secure credit environment than Estonia (ranked 6) throughout the analysed period. Nevertheless, these scores ought to be interpreted with considerable caution. Neither jurisdiction offers a high level of practical protection in the event of litigation (a prerequisite for successful bankruptcy proceedings): an issue re-examined in this paper.

The Credit Information Index (Doing Business 2009) has been designed to measure the "depth" (detail) and "breadth" (scope) of corporate credit information available from public or private sources in a given economy. In line with the index scores for Estonia (5) and Poland (4), unchanged for the past five years, the Estonian economy has consistently offered a slightly higher quality of credit transparency, a major factor from the credit "due diligence" standpoint.

A equally important benchmark of credit transparency relates to the comprehensiveness of public/private registry coverage (as a percentage of the adult population) in respect of data on repayment history, unpaid debts or credit outstanding for the preceding five years: Doing Business (2009). No unified public registry of this sort has been noted in either economy, whereas the Polish private registry system has conspicuously outperformed its Estonian equivalent in 2005-2009. This has mirrored a 
number of reforms implemented in Poland with a view of enhancing the quality of information on "bad debt (-ors)".

\subsection{Investor protection strength (disclosure, director liability, shareholder lawsuits) in Estonia and Poland in 2006-2009}

Investor protection standards matter increasingly more in an era of globalisation, capital flight and conflicting interests among (often diverse) shareholder groups. The Doing Business (2009) database offers a proxy for how effectively countries tend to protect minority investors in the hypothetical event of an "unfair" (albeit not necessarily fraudulent) transaction concluded with the majority shareholder, Djankov et al. (2008a). According to the assumed scenario, the dispute has to be resolved through the corporate governance and legal system. It how it will be processed by this system that matters most to the investor universe.

The Extent of Disclosure Index (Doing Business 2009) provides insight into disclosure practices in such a situation (shareholding voting, mandatory public disclosure, inclusion in a corporate annual report, mandatory disclosure to the board of directors and to an external auditor). The index ranges from 0 (worst) to 10 (best). In 2006-2009, Estonia posted a static 8, while Poland a constant 7 on such a scale.

Liability of company directors, as per the Director Liability Index (Doing Business 2009), comprises the following factors: directors' and chief executive officers' suability for damages, possibility of rescission by court (in case of proven fraud or bad faith) with regard to a corporate action, effectives of damages payment and repayment of unfair profits, criminal penalties as well as availability of direct and derivative litigation.

The extent of director liability in Estonia (3) and Poland (2) must be viewed as rather unsatisfactory (on a scale from 0 to 10 ). This mirrors the negligible personal responsibility borne, in practical circumstances, by company officers for corporate actions performed on behalf of companies. No betterment whatsoever has been recorded in either country in the period of 2006-2009.

The Shareholder Suits Index, as explained under the (Doing Business 2009) methodology, measures various aspects of litigation effectiveness: scope of documentation available to the shareholder claimant (otherwise referred to as "plaintiff"), the claimant's ability to question the defendant or witnesses during trial, to request a government probe into the case without litigating, the shareholder's right of inspecting documentation prior to filing suit and a lesser burden of proof/persuasion for a civil lawsuit than for a criminal case - to which the assumption of innocence ("indulged in the absence of contrary evidence") applies, cf. Hamer (2007). On the index scale from 0 to 10, Estonia has scored a constant 5.7 in 2006-2009. Poland improved minimally (from 5.7 to 6.0 in 2007) and has remained unaltered through 2009.

\subsection{Paying taxes (number of taxes, tax settlement time, total tax rate)}

Taxes play a vital role in a business environment. This recognition has - over the past decade - led a number of governments around the world to use it as a competitive 
tool in economic policy through tax reforms: emergence of tax havens, creation of special economic zones (with low tax regimes) and growing simplification of tax systems, e.g. via introduction of flat taxes; recent experience related to flat tax reform in Russia can be retrieved from Gorodnichenko et al. (2008).

Under the Doing Business methodology, Djankov et al. (2009), a typical company has been chosen to exemplify prevalent business conditions in a country.

The Tax Payments Indicator is aimed a quantifying the total number of taxes and fiscal contributions payable in a given fiscal jurisdiction. Unsurprisingly, the ease of doing business exhibits negative correlation with the quantity of taxes and quasi-taxes that have to be addressed in a given economy.

In this regard, Estonia (10 tax payments throughout 2006-2009) appears to be significantly more liberal than Poland (40 tax payments in 2006, 2007 and 2009 and 41 in 2008). Businesses filing their taxes in Poland usually perceive the fiscal system as relatively complicated and oftentimes necessitating the assistance of professional advisors, which adds to the risk and cost of doing business.

The comparison reflects a flat tax introduced in Estonia back in 1994, alongside a series of deregulatory measures implemented by this country over the past two decades (including the abandonment of certain taxes). Poland has managed to achieve some progress in reforming corporate taxes, yet the overall (largely progressive and opaque) system remains rather incongruous and internationally uncompetitive.

The time needed to comply with the domestic fiscal system (i.e. prepare, file and pay fiscal dues) further epitomises differences in business friendliness between both regimes. In 2006-2009, it has taken an average of 81 hours (slightly over three days) for an Estonian to square up with the taxman, as opposed to some 418 hours (almost two and a half weeks) in Poland. To a business entity, the very act of tax preparation represents negative value: not only does a company have to share part of its profits with the government (the very nature of taxation), but it is oftentimes de facto coerced into retaining the services of external advisers (costly) to cut through the fiscal red tape.

According to Doing Business (2009), the Total Tax Rate Ratio scales the amount of taxes and mandatory contributions (quasi-taxes) payable by the business in the second year of operation, expressed as a share of commercial profits. Pursuant to this methodology, fiscal burdens fall into the following five categories: profit or corporate income tax, social contributions and labour taxes paid by the employer (for which all mandatory contributions are included, even if paid to a private entity such as a requited pension fund), property taxes, turnover taxes and other small taxes (such as municipal fees and vehicle and fuel taxes). The Doing Business Methodology (2009) defines commercial profits as sales minus cost of goods sold, minus gross salaries, minus administrative expenses, minus other expenses, minus provisions, plus capital gains (from the property sale) minus interest expense, plus interest income and minus commercial depreciation.

Surprisingly, Estonia has relatively overburdened its businesses with fiscal levies (in relation to profits), if compared with Poland. In 2006-2009, the aforementioned total tax rate has consumed about $50.0 \%$ of corporate earnings in Estonia, whereas about $40.0 \%$ in Poland. In interpreting the results, caveats need, nonetheless, be sounded. Firstly, both 
countries differ in respect of estimated proportions of economic activity alluding statistical, let alone fiscal accountability (i.e. classified as the so-called "grey" or "informal" economy). Arguably, the "informal economy" concept, coined by Hart (1973), is likely to be deeper ingrained in Poland than in Estonia (vide - earlier comments on socio-economic, historical and political factors and later remarks on business transparency). Secondly, a fair amount of latitude exists in recognising profits, costs and depreciation under both fiscal/accounting systems, wherein the very definitions of many accounting and taxation terms do not entirely overlap (despite ongoing convergence with International Financial Reporting Standards, IFRS); more on the character of "creative accounting" practices in Mulford and Comiskey (2002). Thirdly, for small and medium enterprises (SMEs) divisions between "corporate" and "personal" income (and resultant taxation) frequently tend to blur.

\subsection{Trading across borders (documents, time and cost involved in importing and exporting) in Estonia and Poland in 2006-2009}

Foreign exchange of products and services continues its long-term expansion, as worldwide economies become more and more interdependent (globalisation). The Doing Business database contains a measure of "trading across borders", i.e. openness to international commerce, Djankov et al. (2008b). It is noteworthy that both countries (Estonia and Poland) joined the European Union (EU) in 2004, they have also been members of the World Trade Organisation (WTO) since 1999 (Estonia) and 1995 (Poland). The conditions enabling membership of the EU are available from the respective organisational web sites: European Union On-Line (2009) and WTO (2009).

The Doing Business (2009) Export/Import Documents Indices endeavour to quantify the number of documents required to export or import a standardised cargo of goods by ocean transport. In this comparison, Estonia (with 3 documents needed in exports and 4 in imports) has seemed less bureaucratic than Poland ( 5 documents both for exports and imports) in all 2006-2009.

The time necessary to comply with export/import formalities is regarded as another proxy for constraints in foreign trade activity. Intriguing insights can be gained by comparing how laborious exportation and importation is, on average, in both countries. Estonia (with 5 days for exports and 4 for imports) seems deregulated if compared with Poland (some 17 days for exports and 5 for imports) for 2006-2009. Oddly for an emerging economy (whose past growth has been driven, to a large extent, by brisk exportation), Poland seems by far stricter in monitoring outbound (than inbound) trade flows - at least judging by the compliance efforts involved.

Finally, costs attributable to exportation and importation figure prominently in the business models of entities active in foreign trade. In conformity with the Doing Business (2009) methodology, their scale has been expressed by the fees levied on a 20 -foot container in USD.

Such costs differ considerably between Estonia and Poland basing on Doing Business (2009) estimates. In Estonia, it has taken USD 675 in costs to import and export a standardised container in 2006-2008. In 2009, the estimated costs have risen to USD 
730 for exports and USD 740 for imports. In Poland, both exportation and importation costs have amounted to a flat USD 834 in 2006-2009.

\subsection{Enforcing contracts (judicial efficiency measured by the number of procedures, time and cost) in Estonia and Poland in 2005-2009}

The readiness of legal remedies helps to illustrate a judiciary's efficiency in resolving a commercial dispute, an essential prerequisite to capital formation in a developing economic environment. Under the Doing Business methodology, Djankov et al. (2003), the dispute concerns a lawful transaction (between a buyer and a seller) whose value is tied to a country's twofold per-capita income. The hypothetical dispute (over the quality of goods having been sold) is assumed to be resolved in the seller's favour; no appeal is lodged and the judicial judgment becomes final. The indices measure the pace of evolution of such a dispute before local courts.

The number of procedures mandatory to see a commercial claim through a local court system has been similar in both countries. In Estonia, it has been 37 in 2005-2007 and 36 in 2008-2009. For Poland, this measure of bureaucracy has stood at 38 throughout 2005-2009 (no progress noted).

Time, a key factor in redressing a claim, is of the essence to a business whose proceeds (and sometimes the very fact of further existence) depend on a speedy outcome of litigation. The patience of a Polish businessperson awaiting an effective legal remedy has to be exercised over a span of some two years and three months. Needless to add, many corporate entities will have gone permanently out of business by that time. In Estonia, this range, albeit prolonged, has been limited to one year and two months. To top it all off, judicial efficacy indices used by Doing Business (2009) assume finality of first instance rulings, whereas in actuality many of them end up being (re)appealed and reversed.

Cost efficiency, which - in conformity with the Doing Business (2009) database is calculated as a percentage of the claim in question and is assumed to be equivalent to $200 \%$ of income per capita, highlights another aspect of contract enforcement. Obviously, entrepreneurs favour regimes with moderate legal expenses required to enforce a claim.

In this respect, Estonia (18.9\%) has offered a more burdensome judicial environment than Poland (12.0\%) in 2005-2009. Evidently, the tardy Polish judiciary has operated more cost efficiently, although it is disputable whether this counterbalances the time disparity between both legal systems.

\subsection{Closing a business (the time, cost and outcome of bankruptcy proceedings involving domestic entities) in Estonia and Poland in 2004-2009}

Bankruptcy efficiency comes as a last criterion for comparing the economic environments of both countries, as per Doing Business, Djankov et al. (2008c).

In order to ensure data comparability, assumptions about the business and the case have been made. Besides country size adjustments, the business is assumed to be a hotel operation whose core asset is downtown property secured by a mortgage. Owing to 
irresolvable liquidity problems and negative net worth, the business defaults on its debt. Too many creditors preclude the owners from seeking an out-of-court settlement. The course of action is thus limited to is a judicially supervised rehabilitation/reorganisation, a liquidation or a foreclosure.

The time needed to complete such a course of action has been measured in calendar years under Doing Business (2009). In Estonia and Poland, it has taken a flat three years to complete bankruptcy proceedings in 2004-2009 (no improvement discerned during that time). Again, such a period, if contrasted with macro- and micro-economic cyclicality, seems rather elongated. Suffice it to say that many creditors will have gone out of business by the time their recovered debt finally starts percolating.

The cost of bankruptcy proceedings (calculated as a percentage of the bankruptcy estate, based on survey responses by bankruptcy practitioners) gives an idea about the efficiency of debt recovery according to Doing Business (2009). During the period for which coverage is available, Estonia has proved to be visibly more productive in bankruptcy formalities (9\%) as opposed to Poland (22\% for 2004-2008 and 20\% for 2009).

Finally, recovery rates (expressed as s cents on the dollar recouped by creditors through the bankruptcy or insolvency proceedings) tend to differ in both countries. Basing on Doing Business (2009) data, Estonia has turned out to be slightly more successful id debt recovery than Poland.

\section{Composition of economic entities in Estonia and Poland in 2001-2008}

As clearly demonstrated in Tables 1 and 2, the corporate sector in both countries has been dominated by small firms (0-9 employees), a concentration particularly evident for Poland: some $95 \%$ of all economic entities in 2001-2008.

Table 1. Structure of Polish economic entities by workforce in 2001-2008

\begin{tabular}{|l|r|r|r|r|r|r|r|c|}
\hline Headcount & $\mathbf{2 0 0 1}$ & $\mathbf{2 0 0 2}$ & $\mathbf{2 0 0 3}$ & $\mathbf{2 0 0 4}$ & $\mathbf{2 0 0 5}$ & $\mathbf{2 0 0 6}$ & $\mathbf{2 0 0 7}$ & $\mathbf{2 0 0 8}$ \\
\hline $0-9$ & $95,2 \%$ & $95,2 \%$ & $95,2 \%$ & $95,1 \%$ & $95,1 \%$ & $95,0 \%$ & $95,0 \%$ & $94,9 \%$ \\
\hline $10-49$ & $3,8 \%$ & $3,8 \%$ & $3,9 \%$ & $4,0 \%$ & $4,0 \%$ & $4,1 \%$ & $4,1 \%$ & $4,1 \%$ \\
\hline $50-249$ & $0,9 \%$ & $0,8 \%$ & $0,8 \%$ & $0,8 \%$ & $0,8 \%$ & $0,8 \%$ & $0,8 \%$ & $0,8 \%$ \\
\hline Over 250 & $0,2 \%$ & $0,2 \%$ & $0,1 \%$ & $0,1 \%$ & $0,1 \%$ & $0,1 \%$ & $0,1 \%$ & $0,2 \%$ \\
\hline
\end{tabular}

Source: (Polish) Central Statistical Office on-line reports (available at: http://www.stat.gov.pl/)

Table 2. Structure of Estonian economic entities by workforce in 2001-2008

\begin{tabular}{|l|c|c|c|c|c|c|c|c|}
\hline Headcount & $\mathbf{2 0 0 1}$ & $\mathbf{2 0 0 2}$ & $\mathbf{2 0 0 3}$ & $\mathbf{2 0 0 4}$ & $\mathbf{2 0 0 5}$ & $\mathbf{2 0 0 6}$ & $\mathbf{2 0 0 7}$ & $\mathbf{2 0 0 8}$ \\
\hline $0-9$ & $86,0 \%$ & $86,5 \%$ & $86,0 \%$ & $87,3 \%$ & $87,8 \%$ & $88,2 \%$ & $88,5 \%$ & $88,8 \%$ \\
\hline $10-49$ & $11,6 \%$ & $11,2 \%$ & $11,5 \%$ & $10,4 \%$ & $10,0 \%$ & $9,7 \%$ & $9,4 \%$ & $9,2 \%$ \\
\hline $50-249$ & $2,2 \%$ & $2,0 \%$ & $2,2 \%$ & $2,1 \%$ & $2,0 \%$ & $1,9 \%$ & $1,8 \%$ & $1,8 \%$ \\
\hline Over 250 & $0,3 \%$ & $0,3 \%$ & $0,3 \%$ & $0,3 \%$ & $0,3 \%$ & $0,3 \%$ & $0,2 \%$ & $0,3 \%$ \\
\hline
\end{tabular}

Source: Statistics Estonia (available at: http://www.stat.ee/) 
Table 3. Corporate structure by activity in Estonia and Poland in 2005

\begin{tabular}{|l|c|c|}
\hline \multicolumn{1}{|c|}{ Industry } & Estonia & Poland \\
\hline Mining \& quarrying & $0.0 \%$ & $0.1 \%$ \\
\hline Construction & $9.8 \%$ & $11.4 \%$ \\
\hline Hotels \& restaurants & $4.0 \%$ & $4.1 \%$ \\
\hline Distributive trades & $35.2 \%$ & $42.1 \%$ \\
\hline Real estate, renting \& business activities & $28.4 \%$ & $19.0 \%$ \\
\hline Manufacturing & $13.4 \%$ & $13.5 \%$ \\
\hline Transport \& communications & $8.5 \%$ & $9.7 \%$ \\
\hline Electricity, gas \& water supply & $0.7 \%$ & $0.1 \%$ \\
\hline
\end{tabular}

Source: Eurostat (2009), available at: http://epp.eurostat.ec.europa.eu/

As in Poland, the share of Estonian enterprises employing over 50 staff has been negligible in 2001-2006 (about 2\%). Undoubtedly, small businesses have stood behind the bulk of entrepreneurial activity in Estonia, with sustained progress, roughly, Polish proportions (Table 2).

The breakdown by corporate activity has also displayed numerous similarities for both countries in 2001-2008 (Table 3). Distributive trades have represented the most vital segment of both economies: a discernible about-turn from the smoke-stack business cultures of the 1980s. Real estate (et al.) has also accounted for a substantial share of Estonian and Polish corporate life, followed by manufacturing and construction. In the analysed period, both countries saw massive investment inflows into their property markets.

\section{The business survival phenomenon in Estonia and Poland in 2001-2009}

Statistical coverage of corporate insolvency events in Estonia and Poland remains patchy and ought to be interpreted with caution due to the following limitations:

- Insolvency practices are subject to considerable legal rigour; their frameworks vary between both jurisdictions: the Polish Bankruptcy and Restructuring Law (2003) and the Estonian Bankruptcy Act (2003), yet the underlying notion relates to a company's inability to service its debt, as it falls due. Comparative studies on both insolvency jurisprudences have recently been compiled in Global Legal Group (2009).

- By virtue of the legal character of insolvency/bankruptcy proceedings, substantial time lags occur between initial evidence of payment woes and the ultimate insolvency declaration. This dilutes potential correlations between insolvency and other economic variables.

- Inconsistent and limited time periods for which data sets are available lengthen the odds of an interpreter of economic phenomena linked to insolvency in Estonia and Poland over the recent decade. It is worth emphasising that the scant data render any in-depth statistical or mathematical modelling futile. 
- Finally, as Coface (2009) and Creditreform (2009) expressly avow, data covering insolvencies and bankruptcies in emerging European economies are not always sufficiently representative and adequately reliable.

Duly mindful of such constraints, it is nevertheless striking to see a dramatic (since 2003: exponential) improvement in business survival in Poland, against a creeping upward trend in insolvencies in Estonia in 2001-2008.

Eurostat (2009), Statistics Estonia (2009) and the Polish Central Statistical Office (2009) provide intriguing insights into the structural features of corporate longevity in both economies. Regrettably, reasonably comparable data for both countries are scant and their series do not match perfectly. Nevertheless, tentative observations can be made thereupon.

As indicated by Table 4, corporate survival in Poland tended to peak for entrepreneurs aged 30-39. Conversely, a larger risk of bankruptcy was run by enterprises led by young individuals (below 30 years of age). At this point, it would not be far-fetched to reiterate that experience matters to successful entrepreneurship, and that the generation

Figure 1. Insolvency declarations in Estonia and Poland in 2001-2008

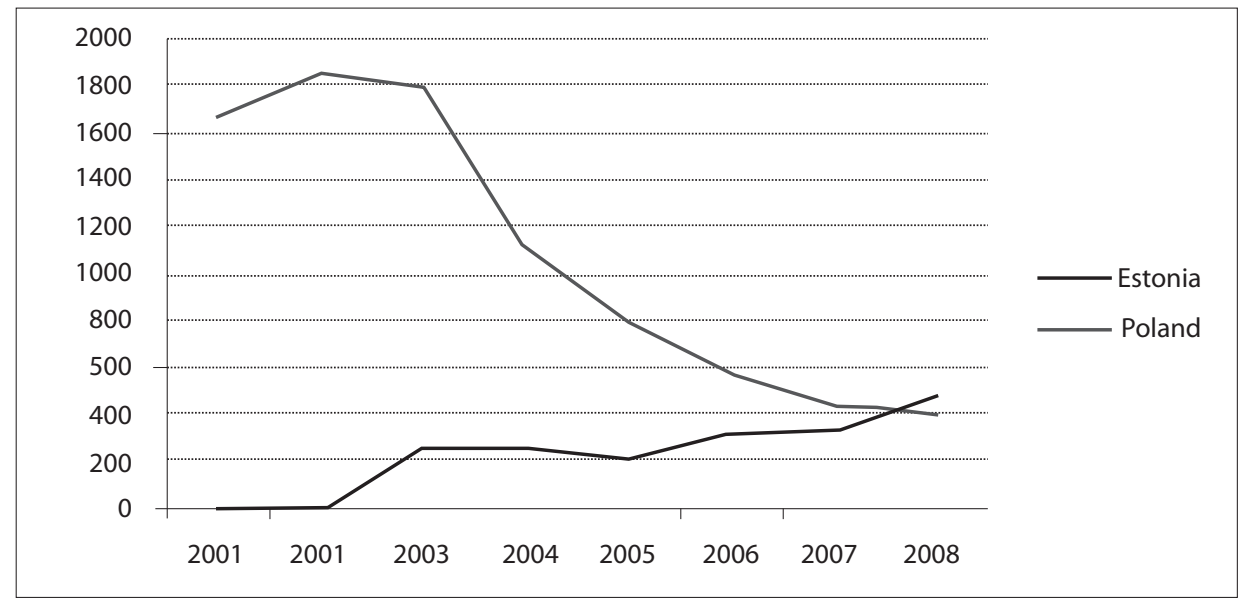

Source: Coface (2009), Creditreform (2009), Eurostat (2009), CIA World Factbook (2009); economic/civil court data. Note: Estonian 1Q2008 civil court estimates have been annualised for all 2008; no data available for insolvencies in Estonia in 2001-2002

Table 4. Enterprises established in Poland in 2002 and continued till 2006 (by entrepreneur's age, in \%)

\begin{tabular}{|c|c|}
\hline Age & Total \\
\hline$<30$ & 39,0 \\
\hline $30-39$ & 46,0 \\
\hline $40+$ & 41,4 \\
\hline
\end{tabular}

Source: Corporate inception, activity conditions and prospects in Poland in 2001-2005, Polish Central Statistical Office, Warsaw, 2007. 
of Polish 30-39-year-olds is, on the one hand, seasoned enough to have witnessed the swift phase-out of communism (commenced there in 1989), subsequent heyday of economic restructuring of the 1990s, as well as the dot.com boom-and-bust of 1998-2001 - whilst, on the other, is sufficiently progressive to have forgotten about the ancien régime.

The Estonian road to free-market democracy began somewhat later than in Poland, i.e. in 1992 (upon the declaration of independence); this time lag is mirrored in corporate continuation statistics - in Estonia tilted towards younger entrepreneurs (Table 5).

Table 5. Enterprises established in Estonia in 2002 and continued till 2005: proportion in main activity (by entrepreneur's age, in \%)

\begin{tabular}{|c|c|c|c|c|c|}
\hline \multirow{4}{*}{ Average } & Age & Industry & Construction & Distributive trades & Other Service \\
\cline { 2 - 6 } & $<30$ & 12.3 & 17.0 & 32.2 & 38.5 \\
\cline { 2 - 6 } & $30-39$ & 11.0 & 16.9 & 31.4 & 40.7 \\
\hline \multirow{3}{*}{ Estonia } & $40+$ & 12.2 & 13.6 & 30.9 & 43.3 \\
\cline { 2 - 6 } & $<30$ & 7.2 & 6.8 & 40.7 & 45.3 \\
\cline { 2 - 6 } & $30-39$ & 11.0 & 7.3 & 40.5 & 41.2 \\
\hline
\end{tabular}

Source: Key figures on European business with a special feature on the factors of business success - Eurostat (2008). Note: the average is based on data covering: Bulgaria, the Czech Republic, Denmark, Italy, Lithuania, Luxemburg, Austria, Romania, Slovakia and Sweden.

In Estonia, apart from the (highly peculiar) extractive sector, corporate survival tended to concentrate around the "health \& social work" as well as "other community, social and personal service activities", i.e. typical "defensive", or "low $\beta$ " sectors (exhibiting limited correlation with general macro-economic cyclicality). The reverse was true for the financial sector (high gearing), wholesaling, retailing and automotive repair (susceptible to the ebb and flow of supply/demand factors), cf. Table 6.

In general terms, Polish enterprises underperformed their Estonian peers at the comparable point in time. In Poland, only $28.2 \%$ of businesses set up in 2001 continued their activity till 2006. In addition, incorporated entities appeared to fare better than sole proprietorships - a probable function of formal capital requirements.

By activity, the worst performers turned out to be hotels and restaurants and contractors of which, respectively, $20.4 \%$ and $23.0 \%$ survived a five year period. Statistically, the safest bets appeared to be placed on industrial operations and construction services (a classical "grey" sector eluding proper coverage in official statistics due to fiscal evasion), cf. Table 7.

Furthermore, numerous research studies have endeavoured to establish causal relationships between key macroeconomic variables (including Gross Domestic Product dynamics) and "corporate demography" in emerging economies, e.g.. Auzina and Pocs (2008). An allusion to the macroeconomic dimension of corporate longevity has also been propounded in the conclusions. 
Table 6. Five-year survival rates of enterprises established in 2000 in Estonia (by economic activity)

\begin{tabular}{|l|c|c|c|c|c|}
\hline \multicolumn{1}{|c|}{ Sector } & $\mathbf{2 0 0 1}$ & $\mathbf{2 0 0 2}$ & $\mathbf{2 0 0 3}$ & $\mathbf{2 0 0 4}$ & $\mathbf{2 0 0 5}$ \\
\hline Economic activities total & $76.2 \%$ & $62.7 \%$ & $55.2 \%$ & $49.9 \%$ & $45.4 \%$ \\
\hline Mining & $100 \%$ & $100 \%$ & $100 \%$ & $100 \%$ & $100 \%$ \\
\hline Manufacturing & $76.6 \%$ & $66.7 \%$ & $58.4 \%$ & $54.1 \%$ & $49.4 \%$ \\
\hline Electricity, gas and water supply & $80.0 \%$ & $80.0 \%$ & $80.0 \%$ & $80.0 \%$ & $60.0 \%$ \\
\hline Construction & $87.3 \%$ & $79.3 \%$ & $68.0 \%$ & $64.7 \%$ & $59.3 \%$ \\
\hline Wholesale and retail trade; repair of motor vehicles etc. & $73.6 \%$ & $58.6 \%$ & $50.7 \%$ & $44.7 \%$ & $40.4 \%$ \\
\hline Hotels and restaurants & $73.6 \%$ & $63.6 \%$ & $57.9 \%$ & $49.6 \%$ & $45.5 \%$ \\
\hline Transport, storage and communication & $83.9 \%$ & $70.0 \%$ & $63.2 \%$ & $57.4 \%$ & $52.0 \%$ \\
\hline Financial intermediation & $70.5 \%$ & $47.7 \%$ & $38.6 \%$ & $38.6 \%$ & $36.4 \%$ \\
\hline Real estate, renting and business activities & $75.1 \%$ & $61.9 \%$ & $55.1 \%$ & $50.4 \%$ & $45.4 \%$ \\
\hline Education & $85.7 \%$ & $67.9 \%$ & $57.1 \%$ & $53.6 \%$ & $50.0 \%$ \\
\hline Health and social work & $95.7 \%$ & $85.1 \%$ & $83.0 \%$ & $83.0 \%$ & $83.0 \%$ \\
\hline Other community, social and personal service activities & $88.3 \%$ & $72.7 \%$ & $68.8 \%$ & $63.6 \%$ & $59.7 \%$ \\
\hline
\end{tabular}

Source: Statistics Estonia (2009), available on-line at: http://www.stat.ee/

Table 7. Percentage of enterprises established in Poland in 2001 and active in 2002-2006 (by legal form and sector)

\begin{tabular}{|c|c|c|c|c|c|}
\hline Item & 2002 & 2003 & 2004 & 2005 & 2006 \\
\hline Total & $64,5 \%$ & $49,2 \%$ & $39,2 \%$ & $31,9 \%$ & $28,2 \%$ \\
\hline \multicolumn{6}{|c|}{ Legal form } \\
\hline Private individuals & $64,4 \%$ & $48,7 \%$ & $38,4 \%$ & $31,1 \%$ & $27,2 \%$ \\
\hline Companies & $66,5 \%$ & $59,4 \%$ & $56,4 \%$ & $51,7 \%$ & $49,0 \%$ \\
\hline \multicolumn{6}{|c|}{ Principal activity } \\
\hline Industry & $64,1 \%$ & $58,9 \%$ & $52,3 \%$ & $43,2 \%$ & $39,9 \%$ \\
\hline Construction & $63,3 \%$ & $44,9 \%$ & $32,2 \%$ & $22,6 \%$ & $23,0 \%$ \\
\hline Trade & $64,4 \%$ & $48,1 \%$ & $36,9 \%$ & $31,9 \%$ & $26,7 \%$ \\
\hline Hotels and restaurants & $56,9 \%$ & $32,0 \%$ & $28,5 \%$ & $23,0 \%$ & $20,4 \%$ \\
\hline Transport & $76,1 \%$ & $60,3 \%$ & $39,7 \%$ & $30,5 \%$ & $27,1 \%$ \\
\hline Construction services & $62,4 \%$ & $48,1 \%$ & $43,4 \%$ & $34,2 \%$ & $30,3 \%$ \\
\hline
\end{tabular}

Source: Corporate inception, activity conditions and prospects in Poland in 2001-2005, Polish Central Statistical Office, Warsaw, 2007.

\section{Conclusions}

The following tentative conclusions can be drawn in respect of economic environments and business survival trends in Estonia and Poland over the past decade:

- Estonian superiority over Poland in the vast majority of critical factors epitomising the quality of institutions and economic environment; the few 
exceptions comprise: hiring difficulty, private credit bureau coverage, total fiscal levies (as part of commercial profits), scale of government and financial sector sophistication.

- The dramatic fall in insolvencies in Poland since 2003, especially if compared to a slow (but discernible) rise in Estonia during the same period, cannot be justified by sheer reasons of systemic (un)friendliness. Overall, Estonia has offered significantly more propitious conditions for entrepreneurship than Poland during the surveyed period.

- Underperformance of Polish enterprises v. Estonian peers in business continuity. Although the Polish progress in cutting corporate insolvencies has been remarkable, Estonian enterprises demonstrated superior business robustness. This peculiarity can be explained by the earlier timing of the business continuity data, as well as non-insolvency impacts (e.g. corporate restructuring, intersectoral migrations, voluntary dissolutions) that resulted in other-than-insolvency business closes.

- Macroeconomic furnishes additional clues as to the survival phenomenon. Although over the past decade, Estonia has outstripped Poland in per-capita Gross Domestic Product (GDP) expansion, Estonian GDP has followed a highly volatile pattern, in contrast to a slower, yet more predictable GDP growth in Poland. Such elevated macro-economic volatility must have corresponded to higher micro-economic risks (increased variance in corporate cash flows, e.g. measurable by $\beta$ ). More on the conceptual foundations of corporate risk measurement (in micro- and macroeconomic settings) can be retrieved from Damodaran (2009).

- Bureaucratic inertia in recognising and enforcing insolvency/bankruptcy events could have worked to the "advantage" of Poland - at least on paper. In simplification, the less efficient a judiciary happens to be in processing insolvency/bankruptcy claims, the more optimistic picture it paints in the short/medium term.

- "Informal economy" scale could (partially) explain the absence of insolvency/bankruptcy events in the official statistics. As stated at the outset, Poland, being a more opaque economy, has a larger proportion of enterprises active in the economic "twilight zone" and under-represented in official statistical reporting.

\section{References}

Auzina A., Pocs R., Overall Macroeconomic Environment Impact on Business Demography, $5^{\text {th }}$ International Scientific Conference - Business and Management 2008, Faculty of Engineering Economics, Riga Technical University; Faculty of Business Management - Vilnius Gediminas Technical University, 2008.

Botero J.C. et al., The Regulation of Labor, Yale University, World Bank, Dartmouth College, National Bureau of Economic Research, Harvard University, 2004.

Central Intelligence Agency (CIA) World Factbook (country profiles), publicly available at: https://www. cia.gov/library/publications/the-world-factbook/index.html, 2009. 
Coface - Coface Group; on line reports available at: http://www.coface.com/, 2009.

Creditreform - Creditreform International; on line reports available at: http://www.creditreform.com/ portal/de/index.jsp, 2009.

Damodaran, A., Comprehensive overview of fundamental corporate finance concepts, including ample on line resources and links to monographs available at: "Damodaran On-Line": http://pages.stern. nyu.edu/ adamodar/, 2009.

Djankov S. et al., Courts, World Bank, Harvard University, Yale University (in co-operation with Lex Mundi), 2003.

Djankov S. et al., The Law and Economics of Self-Dealing, Journal of Financial Economics, no. 88, Elsevier, 2008a.

Djankov S. et al., Trading on time, World Bank, School of Accounting, Economics and Finance, Deakin University, Australia 2008b.

Djankov S. et al., Debt Enforcement around the World, Journal of Political Economy, vol. 116, no. 6, The University of Chicago, 2008c.

Djankov S. et al., Private Credit in 129 Countries, World Bank, Harvard University, Final Draft, 2006.

Djankov S. et al., The Effect of Corporate Taxes on Investment and Entrepreneurship, World Bank, Harvard University, Fourth Draft, 2009.

Djankov S. et al., The Regulation of Entry, Quarterly Journal of Economics, Vol. CXVII, Issue 1, World Bank, Department of Economics, Harvard University School of Management, Yale University, 2002.

Doing Business (Measuring Business Regulations): World Bank on-line database available at: http://www.doingbusiness.org/, 2009.

Doing Business Ranking Methodology, available on-line at: http://www.doingbusiness.org/Methodology Surveys/, 2009.

Estonian Bankruptcy Act, available in Estonian at: http://www.juridica.ee/, 2003.

European Union On-Line - Gateway to the European Union, available on-line at: http://europa.eu/, 2009.

Eurostat - European Commission Statistics Database, available on-line at: http://epp.eurostat.ec.europa. eu/portal/page/portal/eurostat/home, 2009.

Global Legal Group, The International Comparative Legal Guide to Corporate Recovery \& Insolvency (A Practical Insight to Cross-Border Corporate Recovery \& Insolvency), Country Profiles: Estonia, Poland, 2009.

Gorodnichenko Y. et al., Myth and Reality of Flat Tax Reform - Micro Estimates of Tax Evasion and Welfare Effects in Russia, NBER Working Series, Working Paper 13719, National Bureau of Economic Research, Cambridge (MA) 2008.

Hamer D., The Presumption of Innocence and Reverse Burdens: A Balancing Act, The University of Queensland, TC Beirne School of Law Legal Studies Research Paper Series, Paper No. 07-08, 2007.

Hart K., Informal Income Opportunities and Urban Employment in Ghana, The Journal of Modern African Studies, Vol. 11, No. 1, 1973.

Poznańska K., Cykle życia przedsiębiorstw a instytucjonalna infrastruktura ich funkcjonowania (ang. Corporate Life Cycles v. Institutional Infrastructure of Corporate Activity), [in:] Bankructwa przedsiębiorstw. Wybrane aspekty instytucjonalne (ang. Corporate Bankruptcy. Selected Institutional Aspects), (ed.) Mączyńska E., Warsaw School of Economics, Warsaw 2008.

Mulford C.W., Comiskey E.E., The Financial Numbers Game. Detecting Creative Accounting Practices, John Wiley \& Sons, New York 2002.

Polish Bankruptcy and Restructuring Law, available in Polish in the legal database of http://prawo. money.pl/, 2003.

Polish Central Statistical Office, official web site available at: http://www.stat.gov.pl/, 2009.

Preisendorfer P., Voss T., Organizational Mortality of Small Firms: The Effects of Entrepreneurial Age and Human Capital, Organization Studies 11 (1), 1990.

Statistics Estonia, official web site available at: http://www.stat.ee/statistics, 2009.

Transparency International - official web site at: http://www.transparency.org/, 2009.

World Trade Organisation (WTO), official web site at: http://www.wto.org/, 2009. 


\section{Warunki ekonomiczne a kontynuacja działalności przedsiębiorstw w Estonii i Polsce w latach 2001-2009}

\section{Streszczenie}

Przetrwanie przedsiębiorstwa $w$ określonym otoczeniu gospodarczym jest $w$ sposób zasadniczy zdeterminowane jego wewnętrzna konkurencyjnościa, a także czynnikami zewnętrznymi: od łatwości prowadzenia działalności gospodarczej, do uwarunkowań szerszych (makroekonomicznych i strategicznych).

$W$ przedstawionym badaniu zawarto porównanie otoczenia ekonomicznego oraz sektorów przedsiębiorstw dwóch krajów: Estonii i Polski, które w tym samym czasie staty się członkiem Unii Europejskiej. Uogólniając, Estonia, dzięki większej determinacji we wprowadzaniu liberalnych reform rynkowych, po okresie gospodarki nakazowo-rozdzielczej, oferowała w badanym okresie korzystniejsze warunki tzw. ładu korporacyjnego i prowadzenia działalności gospodarczej. Co interesujace, to jednak stabilizacja rozwoju makroekonomicznego Polski zaważyła o lepszych niż w Estonii wskaźnikach „,przeżywalności" przedsiębiorstw. Dane na temat kryzysu ekonomicznego lat 2007-2009 zdaja potwierdzać tę tendencję - przy pogłębiajacej się dywergencji w rozwoju ekonomicznym obu państw. 